\title{
Evaluation of efficacy of saponin and freund's incomplete adjuvanted paratuberculosis vaccine in murine model
}

\author{
Jubeda Begum ${ }^{1}$, Pranabananda Das ${ }^{1}$, Madhu Cholenahalli Lingaraju ${ }^{2}$, Sudhakar Ranjanna ${ }^{3}$, Karuna Irungbam ${ }^{4}$, \\ Anand Mohan ${ }^{1}$ and Radhika Syam ${ }^{1}$
}

1. Division of Biological Products, Indian Veterinary Research Institute, Izatnagar - 243122, Uttar Pradesh, India; 2. Division of Pharmacology and Toxicology, Indian Veterinary Research Institute, Izatnagar - 243122, Uttar Pradesh, India; 3. Division of Parasitology, Indian Veterinary Research Institute, Izatnagar - 243122, Uttar Pradesh, India; 4. Division of Biochemistry, Indian Veterinary Research Institute, Izatnagar - 243122, Uttar Pradesh, India; Corresponding author: Jubeda Begum, Present address: Division of Bacteriology and Mycology, Indian Veterinary Research Institute, Izatnagar - 243122, Uttar Pradesh, India, email: jubedavet@gmail.com

PD: drpdas61@gmail.com, MCL: maddyvet@gmail.com, SR: sudha@gmail.com, KI: kukuirungbam@gmail.com, AM: anand@gmail.com, RS: tinklerose786@gmail.com

Received: 15-04-2014, Revised: 12-06-2014, Accepted: 16-06-2014, Published online: 26-07-2014

doi: 10.14202/vetworld.2014.528-535 How to cite this article: Begum J, Das P, Lingaraju MC, Ranjanna S, Irungbam K, Mohan A and Syam R (2014) Evaluation of efficacy of saponin and freund's incomplete adjuvanted paratuberculosis vaccine in murine model, Veterinary World 7(7): 528-535.

\begin{abstract}
Aim: To compare the efficacy between saponin adjuvanted paratuberculosis killed vaccine and Freund's incomplete (FIC) adjuvanted paratuberculosis vaccine in mice model.

Materials and Methods: The study was conducted for a period of 11 months using 80 Swiss albino mice by dividing into four groups (Group I-mice vaccinated with killed Mycobacterium avium subspp. paratuberculosis (MAP) adjuvanted with saponin, Group II- for FIC, Group III- Saponin control and Gr IV- FIC control). Faecal shedding, changes in body weight, presence of local reactions and clinical symptoms, were evaluated. Serological assays for humoral and cell mediated immune response were determined by agar gel immunodiffusion (AGID) and nitric oxide test (NO) respectively. A total of 76 serum samples, 52 faecal samples and 20 tissue samples were collected at different intervals during the study period. ZN staining; AGID test and nitric oxide test were employed for analysis of samples.

Results: A total of 38 samples ( 37 faecal and 1 tissue sample) and 18 serum samples were recorded as positive by $\mathrm{ZN}$ staining and AGID test respectively from all four groups of mice. Significant decrease in faecal shedding of organisms was observed in Group I mice vaccinated with saponin adjuvanted vaccine in comparison to Group II. Gain in body weight of Group I mice was recorded as higher than Group II. NO test revealed increase in the concentration of NO level in both vaccinated group but more significant in Group I.

Conclusion: The tests results obtained revealed that killed MAP vaccine adjuvanted with saponin have higher protective efficacy in terms of reduced faecal shedding, gain in body weight, less side effects, absence of attributable specific symptoms of Johne's disease, etc. in comparison to killed MAP vaccine adjuvanted with FIC. The present study also reveals that AGID and $\mathrm{NO}$ estimation tests are specific tests which can be employed for diagnosis and comparison of efficacy of paratuberculosis vaccine.
\end{abstract}

Keywords: AGID test, MAP (Mycobacterium avium subspecies paratuberculosis), nitric oxide, saponin and Freund's incomplete adjuvant, Ziehl Neelsen's staining.

\section{Introduction}

Bovine paratuberculosis, also known as Johne's disease (JD), is an incurable, chronic, granulomatous inflammatory disease of the intestines of ruminants and some wild-type species. It is caused by infection with Mycobacterium avium subspp. paratuberculosis (MAP), a mycobactin dependent, slow growing, and acid-fast bacillus. Paratuberculosis is a List B transmissible disease and has trade restriction [1]. Disease is prevalent worldwide $[2,3]$ and causes heavy economic losses due to reduced milk production, veterinary expenses, reduced slaughter value, infertility and premature killing of animals especially in the dairy industry [4-6]. JD causes an annual loss of $\$ 200$ million in United

Copyright: The authors. This article is an open access article licensed under the terms of the Creative Commons Attribution License (http://creativecommons.org/licenses/by/2.0) which permits unrestricted use, distribution and reproduction in any medium, provided the work is properly cited.
States herds alone [7]. Diagnosis of the disease is difficult, expensive and/or low in sensitivity [8-0]. Therapeutic, prophylactic and management strategies for JD are available, but they are difficult and expensive to implement.

In India, the disease is very much prevalent. JD is endemic in developing and developed countries [7]. In India, no thorough survey is carried out but the disease is frequently reported. The disease was first diagnosed in 1913 at Hissar. This is followed by isolated reports from different parts of the country [11-13]. Information on production losses and prevalence of JD in cows at national level has not been estimated. This is due to low priority accorded to JD and lack of national level program conducted by central bodies. Vaccination in cattle against paratuberculosis was first reported by Valle and Ringard in 1926 [14]. Current vaccines available do not fully prevent the disease, instead 
Table-1: Details of samples collected.

\begin{tabular}{|c|c|c|c|c|c|c|}
\hline Group & No. of mice & $\begin{array}{l}\text { Primary innoculation } \\
\left(1^{\text {st }} \text { day }\right)\end{array}$ & $\begin{array}{l}\text { Challenge innoculation } \\
\left(40^{\text {th }} \text { day }\right) \\
\left(10^{9} \mathrm{CFU} / \text { mice }\right)\end{array}$ & $\begin{array}{l}\text { Serum collection } \\
\text { collection }\end{array}$ & Faecal sample & $\begin{array}{l}\text { Post challenge } \\
\text { sacrification of } \\
\text { mice }\end{array}$ \\
\hline Saponin & 25 & Map killed vaccine S/C & Live Map, I/P & $\begin{array}{l}0,7^{\text {th }}, 14^{\text {th }}, 21^{\text {st }}, 28^{\text {th }}, \\
36 \text { th }, 47^{\text {th }}, 54^{\text {th }}, 64^{\text {th }}, \\
74^{\text {th }}, 84^{\text {th }}, 114^{\text {th }}, 144^{\text {th }}, \\
174^{\text {th }}, 204^{\text {th }}, 234^{\text {th }}, 264^{\text {th }}, \\
294^{\text {th }}, 330^{\text {th }}\end{array}$ & $\begin{array}{l}30^{\text {th }}, 43^{\text {th }}, 50^{\text {th }}, 58^{\text {th }}, \\
73^{\text {th }}, 113^{\text {th }}, 143^{\text {th }}, 173^{\text {th }}, \\
203^{\text {th }}, 233^{\text {th }}, 263^{\text {th }} \\
293^{\text {th }}, 330^{\text {th }},\end{array}$ & $\begin{array}{l}100^{\text {th }}, 160^{\text {th }}, 220^{\text {th }} \\
280^{\text {th }}, 330^{\text {th }} .\end{array}$ \\
\hline FIC & 25 & Map killed vaccine S/C & Live Map, I/P & $\begin{array}{l}0,7^{\text {th }}, 14^{\text {th }}, 21^{\text {st }}, 28^{\text {th }}, \\
36 \text { th }, 47^{\text {th }}, 54^{\text {th }}, 64^{\text {th }}, 74^{\text {th }} \\
84^{\text {th }}, 114^{\text {th }}, 144^{\text {th }}, 174^{\text {th }} \\
204^{\text {th }}, 234^{\text {th }}, 264^{\text {th }}, 294^{\text {th }}, \\
330^{\text {th }}\end{array}$ & $\begin{array}{l}30^{\text {th }}, 43^{\text {th }}, 50^{\text {th }}, 58^{\text {th }}, \\
73^{\text {th }}, 113^{\text {th }}, 143^{\text {th }}, 173^{\text {th }}, \\
203^{\text {th }}, 233^{\text {th }}, 263^{\text {th }}, \\
293^{\text {th }}, 330^{\text {th }}\end{array}$ & $\begin{array}{l}100^{\text {th }}, 160^{\text {th }}, 220^{\text {th }}, \\
280^{\text {th }}, 330^{\text {th }}\end{array}$ \\
\hline $\begin{array}{l}\text { Saponin } \\
\text { control }\end{array}$ & 15 & $\begin{array}{l}\text { Saline +Saponin } \\
\text { adjuvant, S/C }\end{array}$ & Live Map, I/P & $\begin{array}{l}0,7^{\text {th }}, 14^{\text {th }}, 21^{\text {st }}, 28^{\text {th }}, 36 \text { th, } \\
47^{\text {th }}, 54^{\text {th }}, 64^{\text {th }}, 74^{\text {th }}, 84^{\text {th }}, \\
1144^{\text {th }}, 144^{\text {th }}, 174^{\text {th }}, 204^{\text {th }}, \\
234^{\text {th }}, 264^{\text {th }}, 294^{\text {th }}, 330^{\text {th }}\end{array}$ & $\begin{array}{l}30^{\text {th }}, 43^{\text {th }}, 50^{\text {th }}, 58^{\text {th }} \\
173^{\text {th }}, 113^{\text {th }}, 143^{\text {th }}, \\
173^{\text {th }}, 203^{\text {th }}, 233^{\text {th }} \\
263^{\text {th }}, 293^{\text {th }}, 330^{\text {th }}\end{array}$ & $\begin{array}{l}100^{\text {th }}, 160^{\text {th }}, 220^{\text {th }}, \\
280^{\text {th }}, 330^{\text {th }}\end{array}$ \\
\hline FIC control & 15 & Saline+ FIC, S/C & Live Map, I/P & $\begin{array}{l}0,7^{\text {th }}, 14^{\text {th }}, 21^{\text {st }}, 28^{\text {th }}, 36 \text { th, } \\
47^{\text {th }}, 54^{\text {th }}, 64^{\text {th }}, 74^{\text {th }}, 84^{\text {th }}, \\
114^{\text {th }}, 144^{\text {th }}, 174^{\text {th }}, 204^{\text {th }}, \\
234^{\text {th }}, 264^{\text {th }}, 294^{\text {th }}, 330^{\text {th }}\end{array}$ & $\begin{array}{l}30^{\text {th }}, 43^{\text {th }}, 50^{\text {th }}, 58^{\text {th }} \\
73^{\text {th }}, 113^{\text {th }}, 143^{\text {th }}, 173^{\text {th }} \\
203^{\text {th }}, 233^{\text {th }}, 263^{\text {th }} \\
293^{\text {th }}, 330^{\text {th }}\end{array}$ & $\begin{array}{l}100^{\text {th }}, 160^{\text {th }}, 220^{\text {th }}, \\
280^{\text {th }}, 330^{\text {th }}\end{array}$ \\
\hline
\end{tabular}

decrease the faecal shedding and delay the spread of the disease.

For controlling JD, what we need is a better diagnostic test and or an appropriate vaccine which can give solid protection. Most of the diagnostic tools available for the early identification of infected animals are less than satisfactory [15], which limits disease detection. Faecal culture for agent detection is the most sensitive method to identify shedding animals [16], but it is still time-consuming and not suitable to use as screening diagnostic method for the whole herd. Serological tests have been evaluated for rapid detection of both clinically and subclinically infected animals: complement fixation (CF), Agarose Gel Immunodifusion (AGID), and preadsorbed ELISA, out of which AGID is considered to be most specific one. Molecular biology techniques, recently developed, are comparatively reliable but the detection of the disease, in the early phase of the disease, is difficult. Since it is a chronic infection and incubation period is too long, total protection from vaccination is also not possible. Though various types of vaccines have been developed so far, killed vaccine remains the most widely used vaccine in field condition despite minor untoward effects. Therefore, a suitable vaccine which delays the onset of the infection and decrease the shedding of pathogen will be of today's demand. Recently, studies conducted using killed vaccine employing saponin adjuvants have been found to have less side effects [17].

Keeping in view of the above facts and necessity, the present study was undertaken to compare the efficacy of MAP killed vaccine using two different adjuvants, Saponin and Freund's incomplete (FIC) adjuvant.

\section{Materials and Methods}

Ethical approval: Experiments were carried out in accordance with the guidelines laid down by the Institute Animal Ethics committee for the use of animal subjects or that procedures were in compliance with at least the declaration of the National Institutes of Health Guide for Care and Use of Laboratory Animals (approved by Institute Animal Ethics Committee, No.F.1-53/2012-13-J.D. Res).

Animal model and vaccination: The present study was carried out in murine model for a period of 11 months employing 80 healthy mice of about 2 weeks old of either sex. The mice were grouped into 4 groups (Group I, n=25; Group II, n=25; Group III, n=15 and Group IV, $\mathrm{n}=15$ ). MAP killed (ATCC 19698) vaccine adjuvanted with FIC and Saponin adjuvants were prepared as per Sigurdsson et al. [14] with suitable modifications. Group I mice were vaccinated with killed MAP adjuvanted with saponin and Group II mice vaccinated with killed MAP adjuvanted with FIC. On the other hand, Group III and Group IV mice were maintained as Saponin control and FIC control respectively. All the four groups were challenged with infection (inoculum size, $10^{9} \mathrm{CFU} /$ mice) by intraperitoneal route on $40^{\text {th }}$ day after vaccination.

Collection of samples: Faecal samples were collected from each group before (on $30^{\text {th }}$ day after vaccination) and after challenge infection $\left(40^{\text {th }}\right.$ day) on $43^{\text {th }}, 50^{\text {th }}, 58^{\text {th }}$, $73^{\text {th }}, 113^{\text {th }}, 143^{\text {th }}, 173^{\text {th }}, 203^{\text {th }}, 233^{\text {th }}, 263^{\text {th }}, 293^{\text {th }}, 330^{\text {th }}$ day and stored at $4{ }^{\circ} \mathrm{C}$ until further processing (Table-1). While serum samples were collected on 0 day before vaccination, $7^{\text {th }}, 14^{\text {th }}, 21^{\text {st }}, 28^{\text {th }}, 36^{\text {th }}$ day after vaccination and $47^{\text {th }}, 54^{\text {th }}, 64^{\text {th }}, 74^{\text {th }}, 84^{\text {th }}, 114^{\text {th }}, 144^{\text {th }}, 174^{\text {th }}, 204^{\text {th }}$, $234^{\text {th }}, 264^{\text {th }}, 294^{\text {th }}, 330^{\text {th }}$ day after challenge infection and stored at $-20^{\circ} \mathrm{C}$ for future use (Table-1). Following euthanization, 2-3 mice were sacrificed and tissue samples (spleen, liver and intestine) were collected from four groups of mice after challenge infection on $100^{\text {th }}, 160^{\text {th }}, 220^{\text {th }}, 280^{\text {th }}, 330^{\text {th }}$ day and stored at $-80^{\circ} \mathrm{C}$ until further processing (Table-1).

Clinical signs and symptoms: Different groups of mice were observed for presence of any specific sign and symptoms attributable to JD. Changes in body weight in different groups at different interval periods, local reactions, changes in necropsy, etc. if present in any group were recorded during the study period. 


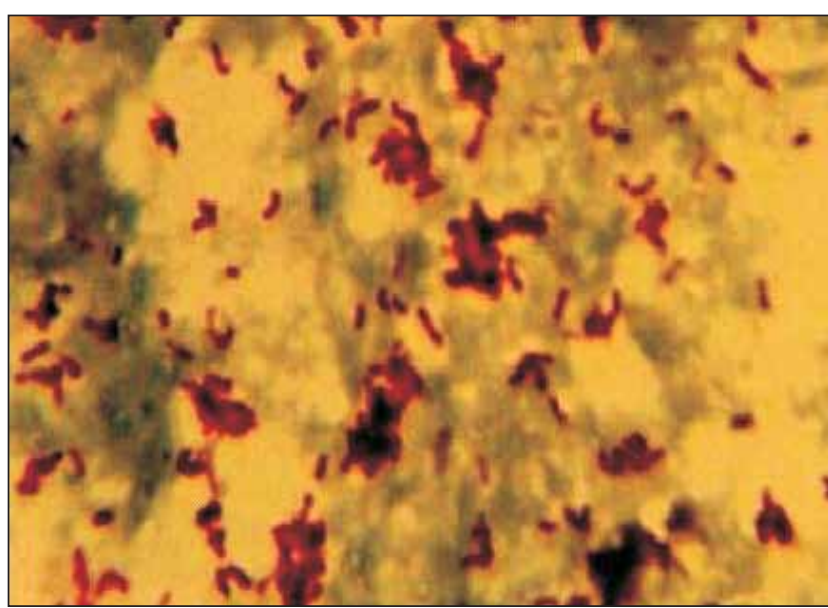

Figure-1: Acid fast bacilli observed under oil immersion after Ziehl Neelsen's staining.

Acid fast staining: Slides in duplicate were prepared after faecal decontamination with $0.75 \%$ HPC (Hexadecylpyridium chloride) and observed by ZN staining. $\mathrm{ZN}$-stained smears of faeces were examined microscopically. In case of tissue samples, 1 gram of tissue was suspended in $3 \mathrm{ml}$ sterile PBS (pH 7.4) in a pestle and mortar and homogenized. Smears prepared from pellet after centrifugation were heat fixed and stained with $\mathrm{ZN}$ staining procedure. A presumptive diagnosis of paratuberculosis is made if clumps (three or more organisms) of small $(0.5-1.5 \mu \mathrm{m})$, strongly acid-fast bacilli are found (Figure-1).

Sonicated antigen preparation: Sonicated antigen was prepared from ATCC 19698 strain M. avium sub species paratuberculosis procured from Division of Biological Products, IVRI, U.P. India. Culture was grown in the Middlebrook 7H10 synthetic media for six weeks at $37^{\circ} \mathrm{C}$ and was killed by autoclaving $\left(120^{\circ} \mathrm{C}\right.$ at $15 \mathrm{lb}$ pressure) for 5 minutes before harvesting the bacterial cells on Whatman No. 1 filter paper. The bacterial cells were washed thrice in sterile phosphate buffer solution (PBS, $50 \mathrm{mM}$ phosphate, $150 \mathrm{mM}$ $\mathrm{NaCl}, \mathrm{pH}$ 7.4) by centrifugation at $5000 \mathrm{rpm}$ for 30 minute. About $5 \mathrm{~g}$ of washed cells were suspended in $10 \mathrm{ml}$ of PBS containing $0.2 \mathrm{mM}$ phenyl methyl sulfonyl fluoride (PMSF) and sonicated at 16 micron amplitude for 3 minute for 15 cycles with a interval of 2 minute between every 3 cycles. Sonicated preparation was centrifuged at $12000 \mathrm{rpm}$ for 1 hour at $4^{\circ} \mathrm{C}$. The supernatant was filtered through $0.22 \mu \mathrm{m}$ membrane filter. The protein content was estimated by the method of Lowry et al. [18] and was found to be $2.05 \mathrm{mg} / \mathrm{ml}$. The sonicated antigen was aliquoted in small eppendorfs and stored at $-20^{\circ} \mathrm{C}$ for its use in AGID test.

AGID test: $0.85 \%$ agarose gel was prepared in PBS (pH 7.4) containing sodium azide $0.02 \%$. Depending on the number of sample to be tested, gel was either poured into the microslides or petridishes, allowed to solidify at $4^{\circ} \mathrm{C}$ for 1 hour in humid chamber. Wells of $5 \mathrm{~mm}$ diameter were punched out in hexagonal pattern of six peripheral wells for sera and one center well for the antigen maintaining equidistance of $5 \mathrm{~mm}$ between them. The central well was filled with sonicated antigen with optimum concentration $(1 \mathrm{mg} / \mathrm{ml})$. The test sera were charged in duplicate in six peripheral wells and incubated at $4{ }^{\circ} \mathrm{C}$ overnight in humid chamber. On each plate, in one set of positive and negative sera were always included as control well. Gels were examined after 24 and $48 \mathrm{~h}$ and in suspected cases after $72 \mathrm{~h}$. A weak line was scored $1+$ and appearance of one or more lines as strong as that of positive serum was scored as $2+$. Sera testing positive in first instance were reconfirmed for specificity by charging the sera alternatively with known positive serum. Absence of precipitin line was recorded as negative test result.

Nitric oxide (NO) estimation test: $\mathrm{NO}$ was estimated at $0,15,45,90,180,240$ and $330 \mathrm{DPV}$ in the serum samples as per Sastry et al. [19].

Statistical analysis: Effects of adjuvant type and antigen on ante-mortem vaccine site reactions, fecal shedding, and body weight were analyzed by appropriate statistical analysis tests. A p-value of $<0.05$ was considered significant.

\section{Results}

Clinical signs and symptoms: Distinct clinical signs and symptoms attributable to JD were not observed in any of challenged mice in Group I and Group II during the entire study period. However, at approximately 9 to 10 months post-challenge infection, few of mice began to show clinical signs like emaciation and muscle wasting without diarrhoea.

Effects of vaccine on ante-mortem vaccination site reaction: Tissue reaction at the site of vaccinations for both Group I and II were recorded. Typical vaccine site reactions were observed with FIC adjuvanted MAP killed vaccine. Reactions characterized by localized, hot and inflammatory swelling of the subcutis and overlying skin with formation of a variable-sized firm subcutaneous nodule approximately 1-2 weeks postvaccination was observed. Tissue reactions were almost absent in case of mice vaccinated with killed MAP adjuvanted with saponin. 


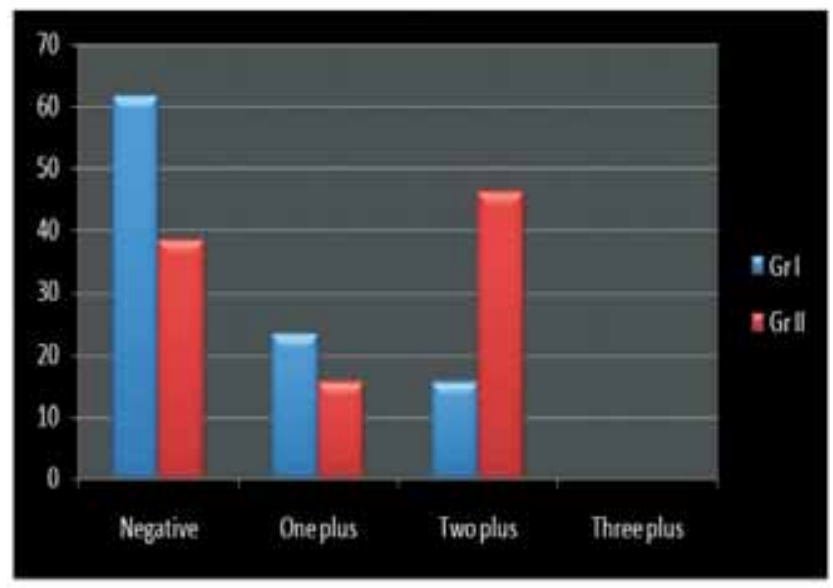

Figure-2: Graph for faecal shedding in percentage at different intervals during the study period.

Table-2: Faecal shedding in different groups evaluated by Ziehl Neelsen's staining

\begin{tabular}{|c|c|c|c|c|c|c|}
\hline \multirow[t]{2}{*}{ No. of samples (n) } & \multirow[t]{2}{*}{ Group } & \multicolumn{4}{|c|}{ Level of shedders } & \multirow[t]{2}{*}{ No. of positive samples } \\
\hline & & - & + & ++ & +++ & \\
\hline 13 & Group I & 8 (61.54\%) & $3(23.07 \%)$ & $2(15.38 \%)$ & 0 & $5(38.46 \%)$ \\
\hline 13 & Group II & $5(38.46 \%)$ & $2(15.38 \%)$ & $6(46.15 \%)$ & 0 & $7(61.54 \%)$ \\
\hline 13 & Group III & $1(7.69 \%)$ & $1(7.69 \%)$ & $6(46.15 \%)$ & $5(38.46 \%)$ & $12(92.30 \%)$ \\
\hline 13 & Group IV & $1(7.69 \%)$ & $1(7.69 \%)$ & $6(46.15 \%)$ & $5(38.46 \%)$ & $12(92.30 \%)$ \\
\hline Total $n=52$ & & $15(28.85 \%)$ & $7(13.46 \%)$ & $20(38.46 \%)$ & $10(19.23 \%)$ & $37(71.15 \%)$ \\
\hline
\end{tabular}

Group I (Saponified MAP killed vaccine + challenge infection), Group II ( FIC adjuvanted MAP killed vaccine + challenge infection), Group III (Saponin adjuvant + challenge infection), Group IV ( FIC adjuvant + challenge infection)*23.08\% (-), $7.69 \%(+)$ and $30.77 \%(+++)$ reduction in faecal shedding were recorded in Group I in comparison to Group II depending upon the level of shedding with $p<0.0001$. In case of tissue samples, only one sample (5\%) from Group IV was recorded as positive out of 20 samples.

Table-3: Changes in body weight of mice before and after challenge infection in different groups.

\begin{tabular}{|c|c|c|c|c|c|c|}
\hline \multirow{2}{*}{$\begin{array}{l}\text { No. of mice in } \\
\text { each group }\end{array}$} & \multirow[t]{2}{*}{ Group no. } & \multicolumn{5}{|c|}{ Average body weight change $(\mathrm{g})$ at different intervals during the study period } \\
\hline & & $\begin{array}{l}14 \text { days (age at time } \\
\text { of vaccination ) }\end{array}$ & $\begin{array}{l}60 \text { days (age at time of } \\
\text { challenge infection) }\end{array}$ & 130 days & 220 days & 330 days \\
\hline $\begin{array}{l}25 \\
25 \\
15 \\
15\end{array}$ & $\begin{array}{l}\text { I } \\
\text { II } \\
\text { III } \\
\text { IV }\end{array}$ & $\begin{array}{l}12 \pm 0.5 \\
12 \pm 0.5 \\
12 \pm 0.5 \\
12 \pm 0.5\end{array}$ & $\begin{array}{l}21 \pm 1.0 \\
20 \pm 0.8 \\
20 \pm 0.5 \\
20 \pm 0.5\end{array}$ & $\begin{array}{l}27 \pm 1.0 \\
24 \pm 0.8 \\
22 \pm 0.1 \\
22 \pm 0.1\end{array}$ & $\begin{array}{l}28 \pm 0.3 \\
25 \pm 0.2 \\
18 \pm 0.1 \\
18 \pm 0.1\end{array}$ & $\begin{array}{l}28 \pm 0.4 \\
25 \pm 0.3 \\
16 \pm 0.5 \\
16 \pm 0.5\end{array}$ \\
\hline
\end{tabular}

Effect of vaccine on gross pathology: No significant gross changes were observed at necropsy in all the four groups during the study period. Gross changes were completely absent from Group I and Group II while enlargement of spleen and liver were observed in few mice in control challenged groups.

Effect of vaccine on body weight of mice: Prior to challenge infection, the body weights were almost same in all four groups. After challenge infection, changes in body weight of mice in different groups were observed (Table-3). Body weight gain in mice of vaccinated groups were analyzed by analysis of variance (ANOVA), Group I and Group II were recorded but the body weight gain was more in Group I in comparison to Group II $(\mathrm{p}<0.05)$. No significant changes were observed in Group III and Group IV control group.

Effect of vaccine in faecal shedding of mice: Faecal shedding in different groups of mice was determined by ZN staining and analyzed by ANOVA. Out of total $\mathrm{n}=52$ faecal samples with 13 samples each from the four groups, in Group I, only 5 (38.46\%) samples were recorded as positive, 7 (61.54\%) samples in Group II, $12(92.30 \%)$ from Group III and $12(92.30 \%)$ from Group IV (Figure-2).

Significant decrease in faecal shedding was observed in both vaccinated groups, Group I and Group II but decrease in shedding was more significant in Group I by $23.08 \%(\mathrm{p}<0.05)$ in comparison to Group II (Table-2, Figure-2). While in Group III and Group IV, the shedding rate was increased in the first 3-6 months followed by intermittent shedding which continues upto $10^{\text {th }}$ month post challenge infection. In case of tissue samples, only one sample $(5 \%)$ from Gr IV was recorded as positive out of 20 samples.

AGID test result of serum samples: Out of total 76 serum samples tested, 18 (24\%) samples (2 from Group I, 3 from Group II, 6 from Group III and 7 from Group IV) were recorded as positive for AGID test (Figure-3, Table-3). Of the positive samples, 16 (21\%) samples $(2$ from Group I, 3 from Group II, 5 from Group III and 6 from Group IV) were recorded as positive with +1 
Table-4: Details of Agar Gel immunodiffusion test results.

\begin{tabular}{|c|c|c|c|c|c|}
\hline \multirow[t]{2}{*}{ No. of samples (n) } & \multirow[t]{2}{*}{ Group } & \multicolumn{3}{|c|}{ Scoring of AGID test } & \multirow[t]{2}{*}{ No. of positive samples } \\
\hline & & - & +1 & +2 & \\
\hline $\begin{array}{l}19 \\
19 \\
19 \\
19 \\
\text { Total } n=76\end{array}$ & $\begin{array}{l}\text { Group I } \\
\text { Group II } \\
\text { Group III } \\
\text { Group IV }\end{array}$ & $\begin{array}{l}17(89.47 \%) \\
16(84.21 \%) \\
13(68.42 \%) \\
12(63.15 \%)\end{array}$ & $\begin{array}{l}2(10.52 \%) \\
3(15.78 \%) \\
5(26.31 \%) \\
6(31.57 \%)\end{array}$ & $\begin{array}{c}0 \\
0 \\
1(5.26 \%) \\
1(5.26 \%)\end{array}$ & $\begin{array}{c}2(2.63 \%) \\
3(3.94 \%) \\
6(7.89 \%) \\
7(9.21 \%) \\
18(23.68 \%)\end{array}$ \\
\hline
\end{tabular}

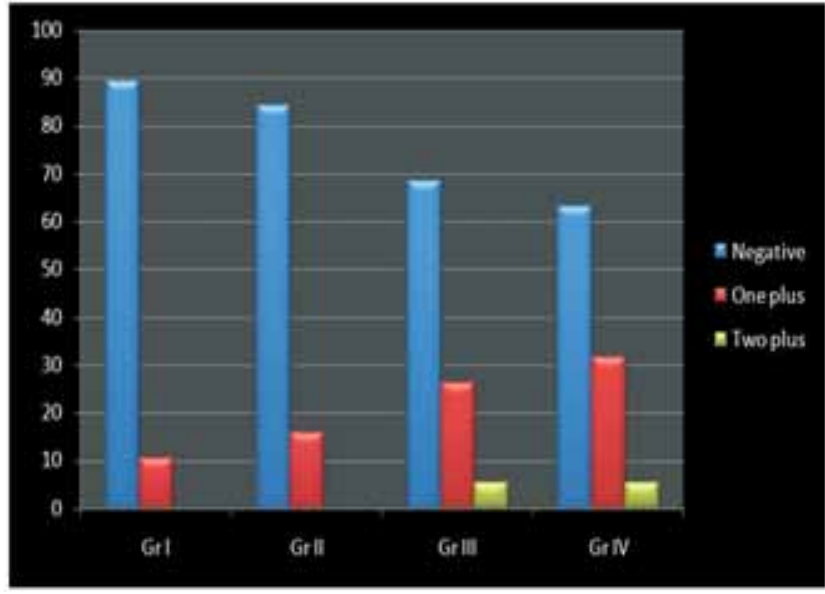

Figure-3: Graph for AGID test in percentage score recorded during the study period.

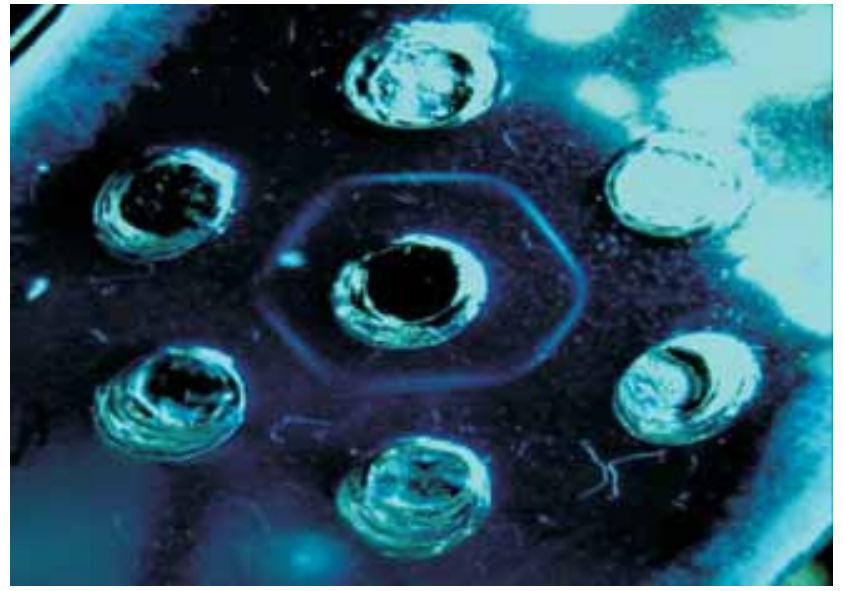

Figure-4: AGID test positive result showing the clear precipitin bands.



Figure-5: Graph for Nitric oxide test depicting nitric oxide level at different intervals during the study period.

score (weak band) and only 2 (16\%) samples (1 from Group III and 1 from Group IV) were recorded as positive with score of +2 (strong band) (Table- 4 , Figure-3 and 4)

NO estimation test: It was carried out in serum samples on $0,15,45,90,180,240$ and 330 days during the study period and analyzed by ANOVA. At 0 DPV, concentration of $\mathrm{NO}$ in serum was comparable among the 4 groups, but afterwards in vaccinated groups Group I and II had higher NO concentration than Group III and IV $(p<0.0001)$. In between Group I and Group II also, Group I was recorded with higher nitric oxide concentration (Figure-3). At 45 DPV and onward sampling intervals, Group I vaccinated group had significantly higher $(p<0.0001)$ concentration of $\mathrm{NO}$ as compared to Group II. In Group I and Group II, peak NO concentration was recorded at $45 \mathrm{DPV}$ and sub-sequently concentration declined slightly at 90 DPV. After 90 DPV at each sampling interval, mice in both vaccinated groups maintained NO concentration with slight up and down but Group I remained higher than Group II vaccinated mice at all the post-vaccination intervals (Figure-5).

\section{Discussion}

Vaccination is regarded as the easy and cost effective method for controlling MAP infection in animals. In the present study saponin adjuvant was used in vaccine preparation with the aim to modulate cell mediated immune system which is most important for protection against JD. Saponin based adjuvants have the ability to modulate the cell mediated immune system as well as to enhance antibody production and have the advantage that only a low dose is needed for adjuvant activity [20]. Saponins induce a strong 
adjuvant effect to T-dependent as well as T-independent antigens [21]. Vaccines adjuvanted with QS21 were found to have less systematic side effects than vaccines adjuvanted with alum [16]. Best performances in protection and reduction of necropsy lesions at 9 months post challenge were obtained with CWCQS21 vaccine. It is generally agreed that protection against mycobacterial disease is mainly due to TH1 cells that produce IFN- $\gamma$ to activate macrophages which then kill mycobacteria during phagocytosis [22].

In the present study, gross pathological changes attributable to JD were absent. This might be due to prolong incubation period of the disease as well as subclinical infection which is most frequent in case of JD. In addition, it is reported that symptoms and necropsy changes specifically intestinal lesions were less common in mice model [23].

Changes in body weight of mice prior to vaccination and at 0 DPV were almost same, significant difference in body weight were observed after challenge infection in all the four groups. In Group I, gain in body weight was observed upto 330 day of study period but significant changes in body weight was observed during first 2-3 months post vaccination. Likewise, in Group II also, body weight gain was recorded but the changes observed were less in comparison to Group I. In case of Group III and IV control groups with challenge infection, changes in body weight were slow and less in comparison to Group I and II. Also, in Group III and IV, loss in weight was recorded from 220 days onwards. Overall, both the vaccinated groups showed significant gain in body weight in comparison to both control groups (Table-3). Similar findings were reported in goat by Singh et al. [24].

Faecal shedding of MAP is one of the common factors in spreading the disease. Therefore, controlling the rate of shedding would be important for controlling JD. In our present study, reduction in faecal shedding were recorded in both the vaccinated groups, Group I and II, but the reduction rate were more in Group I than Group II (Table-2, Figure-2). In control groups, the rate of shedding was higher in the first 3 months of challenge infection followed by intermittent shedding upto 330 days. It has been reported that vaccination reduces the faecal shedding or delayed the time of shedding [25-27].

The AGID test is useful for the confirmation of the disease in clinically suspect cattle, sheep and goats [28]. It has been reported that in small ruminants in New Zealand and Australia the AGID offers slightly higher sensitivity and specificity than that obtained by the ELISAs [28-30]. The reported specificity and sensitivity of the AGID measured against histological results were $99-100 \%(95 \%$ CI) and 38-56\% (95\% CI), respectively [29]. Some reports estimate that when AGID results are positive, there is a $95 \%$ chance of actual MAP infection in a clinically affected cow [31].

In the present study, AGID detected few samples (only 18 serum samples out of 76 samples) to be positive in comparison to $\mathrm{ZN}$ staining detection which revealed 37 samples as positive out of 52 faecal samples. These results indicate that AGID is one of the specific tests for monitoring humoral immune response in vaccinated and control groups. The test is rapid, inexpensive, and accurate, and it allows for an efficient informed clinical decision. All test results were available within 24 to $48 \mathrm{~h}$. Although faecal culture is a reliable method for diagnosis of paratuberculosis, its practical use for diagnosis of clinical and subclinical infections is seriously impaired by prolong incubation period required for positive results.

In experimentally induced infection of sheep with M. paratuberculosis, it was reported that AGID tests reflected the progress of infection more accurately than other serological tests. The number and density of precipitation bands increased over time in animals in which large numbers of $M$. paratuberculosis were seen in tissues at necropsy. As the clinical disease advanced, precipitating antibody responses increased [27].

NO estimation test in serum samples revealed higher NO concentration in vaccinated groups, Group I and Group II but the concentration was higher in Group I in comparison to Group II. Highest NO concentration was recorded on 45 DPV in vaccinated groups. In Group III and IV, no significant changes in concentration were observed.

It is generally believed that reactive nitrogen's, such as NO, are most effective in direct killing of mycobacteria [32]. Significantly higher NO concentration was seen in vaccinated groups (higher in Group I than Group II and least for Group III and Group IV). Increased production of NO induced by antigen may cause effective immune response towards MAP and may lead to inhibition of MAP in macrophages. Similar findings were recorded in study conducted by Singh et al. [33].

The result obtained in the present study predicts that NO estimation test might be a useful assay for monitoring CMI response in the study of JD vaccination and also in comparing the vaccine efficacy among the different vaccine groups.

\section{Conclusion}

Based on the analysis of different factors above and test conducted for $\mathrm{HI}$ and $\mathrm{CMI}$ response at different interval periods during the study period, the present study depicts that comparative efficacy of Saponin adjuvanted MAP killed vaccine above the FIC adjuvanted one in terms of low faecal shedding, absence of specific clinical symptoms, gross pathological changes, significant gain in body weight. AGID employed in the present study also depicts the efficacy in different groups with different scores revealing its specificity in diagnosis. Therefore, saponin adjuvanted MAP killed vaccine might be used for reducing the overall burden of the JD. Future studies can be targeted employing ruminant model accompanied by prolong monitoring for proper analysis of efficacy of saponified MAP 
killed vaccine. Vaccination with whole bacterin - QS21 vaccine in particular might show promising result in future.

\section{Authors' contributions}

PD and JB designed the experiment. JB and MCL performed the experiment. JB, MCL and RS collected the samples. Facility of reagents done by PD, MCL, SR and KI. Instrumentation facility by KI and SR. JB, MCL and AM analysed the data. Manuscript drafted by $\mathrm{PD}, \mathrm{JB}$ and MCL. Manuscript reviewed and revised by JB, PD, MCL, AM and RS. All authors read and approved the final manuscript.

\section{Acknowledgements}

This study was funded by Inspire fellowship (IF120859) programme, Department of Science \& Technology (DST), Ministry of Science \& Technology, Government of India.

\section{Competing interests}

The authors declare that they have no competing interests.

\section{References}

1. OIE Terrestrial Manual (2008) Chapter 2.1.11. Paratuberculosis (Johne's disease).

2. Harris, N.B., Barletta, R.G. (2001) Mycobacterium avium subsp. paratuberculosis in veterinary medicine. Clin. Microbiol. Rev., 14:489-512.

3. Nielsen, S.S., Toft, N. (2009) A review of prevalences of paratuberculosis in farmed animals in Europe. Prev. Vet. Med., 88:1-14.

4. Smith, R.L., Grohn, Y.T., Pradhan, A.K., Whitlock, R.H., Van Kessel, J.S., Smith, J.M., Wolfgang, D.R., Schukken, Y.H. (2009) A longitudinal study on the impact of Johne's disease status on milk production in individual cows. $J$ Dairy. Sci., 92:2653-2661.

5. McKenna, S.L., Keefe, G.P., Tiwari, A., VanLeeuwen, J., Barkema, H.W. (2006) Johne's disease in Canada part II: disease impacts, risk factors, and control programs for dairy producers. Can. Vet. J., 47: 1089-1099.

6. Ott, S. L., Wells, S. J. and Wagner, B. A. (1999) Herd-level economic losses associated with Johne's disease on US dairy operations. Prev. Vet. Med., 40:179-192.

7. Abbas, M., Munir, M., Khaliq, S.A., Ikram Ul Haq, M., Khan, M.T. and Qureshi, Z. A. (2011) Detection of Paratuberculosis in Breeding Bulls at Pakistani Semen Production Units: A Continuous Source of Threat. International Scholarly Research Network ISRN Veterinary Science. Article ID 501235, 4 pages doi:10.5402/2011/ 501235.

8. Lu, Z., Mitchell, R.M., Smith. R.L., Van Kessel, J.S., Chapagain, P.P., Schukken, Y.H., Grohn, Y.T. (2008) The importance of culling in Johne's disease control. J. Theor. Biol., 254:135-146.

9. Mikkelsen, H., Jungersen, G., Nielsen, S.S. (2009) Association between milk antibody and interferon-gamma responses in cattle from Mycobacterium avium subsp. paratuberculosis infected herds. Vet. Immunol. Immunop., $127: 235-241$.

10. Nielsen, S.S., Toft, N. (2007) Assessment of managementrelated risk factors for paratuberculosis in Danish dairy herds using Bayesian mixture models. Prev. Vet. Med., 81: 306-317.

11. Bapat, J. A., Bangi, M. (1985) Tuberculosis and Johne's disease amongst cattle and buffaloes in Maharashtra State. Indian J. Anim. Sci., 55: 1022-1023.
12. Nain, S.P.S., Chandiramani, N.K., Kulshreshtha, R. C., Chugh, S. K. (1985) Studies on tuberculin and Johnin reactors - a preliminary report. Indian. Vet. J., 62: 643-46.

13. Singh, S. V., Singh, A. V., Singh, R. (2008) Sero-prevalence of Bovine Johne's disease in buffaloes and cattle population of North India using indigenous ELISA kit based on native Mycobacterium avium subspecies paratuberculosis 'Bison type' genotype of goat origin. Comp. Immunol. Microb., 31 : 419-433.

14. Sigurdsson, B. (1960) A killed vaccine against paratuberculosis (Johnes disease) in sheep. Am. J. Vet. Res., 21:54.

15. Cocito, C., Gilot, P., Coene, M., De Kesel, M., Poupart, P. and Vennuffel, P. (1994) Paratuberculosis. Clin. Microbiol. Rev., 7: 328-345.

16. Whitlock. R.H., Wells, S.J. and Sweeney, R. (2000) ELISA and fecal culture for paratuberculosis (Johne's disease): sensitivity and specificity of each method. Vet. Microbiol., 77: 387-398

17. Rosseels, V. and Huygen, K. (2008) Vaccination against paratuberculosis. Expert. Rev. Vaccines., 7: 817-832.

18. Lowry, O.H., Rosebrough, N.J., Farr, A.L. and Randall, R.J. (1951) Protein measurement with folin phenol reagent. $J$. Biol. Chem., 193:265-275.

19. Sastry, K.V.H., Moudgal, R.P., Mohan, J., Tyagi, J.S. and Rao, G. S.(2002) Spectrophotometric determination of serum nitrite and nitrate by copper-cadmium alloy. Anal. Biochem., 306 (1) : 79-82, 2002.

20. Oda, K., Matsuda, H., Murakami, T., Katayama, S., Ohgitani, T., Yoshikawa, M. (2000) Adjuvant and haemolytic activities of 47 saponins derived from medicinal and food plants. Biol. Chem., 381(1):67-74.

21. Rajput, Z. I., Hu, S., Xiao, C. and Arijo, A.G. (2007) Adjuvant effects of saponins on animal immune responses. J. Zhejiang. Univ. Sci. B., 8: 153-161.

22. Ronald, B.S.M., Manohar, M.B., Chandran, N.D.J. (2012) Efficacy of killed vaccine with different adjuvants for the control of Johne's disease. Proceedings of the 11th International Colloquium on Paratuberculosis, 5-10 February 2012, Sydney, Australia.

23. Begg, D.J.,Whittington, R.J. (2008) Experimental animal infection models for Johne's disease, an infectious enteropathy caused by Mycobacterium avium subsp. paratuberculosis. Vet. J., 176:129-145.

24. Singh, S. V. Singh, P. K. Singh, M. K. Singh, A. V. and Sohal, J. S. (2013) Therapeutic potential of Johne's disease vaccine: A follow up post vaccination study in a goatherd of endangered Jamunapari breed, naturally infected with Mycobacterium avium subspecies paratuberculosis. Glob.J. Anim. Sci.Livestock Prod.Anim. Breed., 1: 082-094.

25. Patton, E. (2012) Paratuberculosis vaccination. Vet. Clin. North Am. Food Anim. Pract., 27 :573-580.

26. Hines, M.E., Stiver, S., Giri, D.,Whittington, L., Watson, C., Johnson, J., Musgrove, J., Pence, M., Hurley, D., Baldwin, C., Gardner, I.A., Aly, S. (2007) Efficacy of spheroplastic and cell-wall competent vaccines for Mycobacterium avium subsp. paratuberculosis in experimentally-challenged baby goats. Vet. Microbiol., 120:261-283.

27. Sherman, D.M., Markham, R.J.F., Bates, F. (1984): Agar Gel immunodiffusion test for diagnosis of clinical paratuberculosis in cattle. J. Am. Vet. Med. Assoc., 185 (2): 179-182.

28. Hope, A.F., Kluver, P.F., Jones, S.L. and Condron, R.J. (2000) Sensitivity and specificity of two serological tests for the detection of ovine paratuberculosis. Aust. Vet. J., 78 (12): $850-856$.

29. Gwozdz, J.M., Thompson, K.G., Murray, A., Reichel, M.P., Manktelow, B.W. and West, D.M. (2000) Comparison of three serological tests and an interferon-gamma assay for the diagnosis of paratuberculosis in experimentally infected sheep. Aust. Vet. J., 78 (11):779-783.

30. Sergeant, E.S., Marshall, D.J., Eamens, G.J., Kearns, C. and 
Whittington, R.J. (2003) Evaluation of an absorbed ELISA and an agar-gel immuno-diffusion test for ovine paratuberculosis in sheep in Australia. Prev. Vet. Med., 61 (4): 235-248.

31. Tiwari, A., VanLeeuwen, J.A., McKenna, S.L.B., Keefe, G.P., Barkema, H.W. (2006) Johne's disease in Canada Part I: Clinical symptoms, pathophysiology, diagnosis, and prevalence in dairy herds. Can. Vet. J., 47:874-882.

32. Mullerad, J., Hovav, A. H., Nahary, R., Fishman, Y. and Bercovier, H. (2003) Immunogenicity of a $16.7 \mathrm{kDa}$
Mycobacterium paratuberculosis antigen. Microb. Pathog., 34: 81-90.

33. Singh, S.V., Singh, P. K. Singh, A. V., Sohal, J. S. and Sharma, M. C. (2010) Therapeutic Effects of a New "Indigenous Vaccine" Developed Using Novel Native "Indian Bison Type" Genotype of Mycobacterium avium Subspecies paratuberculosis for the Control of Clinical Johne's Disease in Naturally Infected Goatherds in India. Vet. Med. International, Volume 2010, Article ID 351846, 8 pages.

$* * * * * * * *$ 